\title{
St. Paul and Dasuk's Story of Experiencing God
}

\author{
Park Taesik \\ Department of Theology, Sungkonghoe University, Seoul, Korea \\ Email address: \\ parktaesik@yahoo.com \\ To cite this article: \\ Park Taesik. St. Paul and Dasuk's Story of Experiencing God. International Journal of Education, Culture and Society. \\ Vol. 4, No. 2, 2019, pp. 36-41. doi: 10.11648/j.ijecs.20190402.12
}

Received: May 14, 2019; Accepted: June 23, 2019; Published: July 10, 2019

\begin{abstract}
In this article, we will deal with the mysterious experiences of St. Paul, who was the great apostle of Christianity in the first century and Dasuk, the representative spiritual figure of the Korean Church. And we will calculate the aspects of how the experience of God is achieved and the least common multiple aspects of the mystic experience. Paul and Dasuk experienced God. After the experience, Paul was transformed into an apostle for the Gentiles, and Dasuk was born again ('Rebirth Day'). When we compare the experience between the two people, common things that can't be ignored are found. They stood before the eternal present God, untouched by time, through which they experienced the dramatic change. The content of the question of Paul and Dasuk has changed from the ethical level to the existential level. The experience of God is the enlightenment that brings about a Change of Being. Therefore, in life after enlightenment, revelation and calling would never be divided into two. It is an excellent example of Paul, who had spent his entire life as a gospel preacher, and Dasuk, who lived a lifetime as an educator devoted to explaining the words of God.
\end{abstract}

Keywords: St. Paul and Dasuk, Mysticism, Revelation of God, Existential Change, Enlightenment

\section{Introduction}

Mysticism is an ancient tradition of the Church. One of the various aspects of mysticism is to experience God in the midst of meditation and contemplation, not through the framed doctrines given by the Church. Of course, the personal experience can be uncomfortable in the eyes of the institutional church, which emphasizes the official root of all revelation given by God himself. The church, however, instead of rejecting the personal experience that might emanate from the power of the pastor, gave the privilege to the experience of mysticism. The representative example is the privilege granted to the Ordo Contemplativus, contemplative institute. No further, the Church has even made the Ordo Contemplativus ideal for all secular Christians as a Christian community that serves as true faith.

Since the Ordo Contemplativus is a spiritual training community, it does not constitute a hierarchical order like the secular church. If you experience God through spiritual discipline, you are in the best religious position. It, however, does not mean that the Church was just looking at the birth and growth of all the convents. In the history of the Church, many mystical movements and mystical communities have been excommunicated by heresy judgment, and their mysterious experiences have been devastated by demonic operations. In order to discipline heresy, however, the Church must stand a reasonable standard to distinguish between healthy mysticism and unscientific mysticism. This is why Paul's experience of God is important.

In this article, we will deal with the mysterious experiences of St. Paul, who was the great apostle of Christianity in the first century and Dasuk, the representative spiritual figure of the Korean Church. And we will calculate the aspects of how the experience of God is achieved and the least common multiple aspects of the mystic experience. First, let's read the experience of God, which the two people provide directly.

\section{The Mystic Experience of St. Paul}

St. Paul was converted through a dramatic experience. [1] It is possible to ask the question, "Is conversion not correct?" because he became a Christian from a thoroughly Jewish person. However, his idea of God had not changed, but his idea of Jesus had changed. It does not change the object of faith (conversion), but it means that the thought about Jesus has changed (alteration) [2]. 
Paul refers to the experience of revelation several times in his letter. "Am I not free? Am I not an apostle? Have I not seen Jesus our Lord? Are you not the result of my work in the Lord?"(1 Cor 9:1). Paul emphasizes that he saw Jesus, but this verse is not a place to explain Paul's experience of alteration, but rather a description of the legitimacy of his apostolate, so it is not enough to know specifically the process and content of experience. In addition, Paul tells us that he met the resurrected Jesus by putting himself in the list of resurrection witnesses of Jesus in the first century Church (1 Cor 15:5-8) [3]. But this is too short to be seen as a revelation experience. And "Jesus captivated me" (Phil 3:12) is also mentioned, but it is only an implication. A more detailed revelation experience than these texts appears in Gal 1:11-17.

Originally, Paul has much to boast of, as he himself asserted (1 Cor 12), but he did not tell his story, because he devoted himself to the preaching of 'the gospel of Jesus Christ'. But in Gal 1:11-17 he has inevitably released his own affairs which contained the experience of revelation. We can find the reason in Gal 1:6-7, because of "a different gospel" that false preachers came to the Galatians and spread. "I am astonished that you are so quickly deserting the one who called you to live in the grace of Christ and are turning to a different gospel which is really no gospel at all. Evidently some people are throwing you into confusion and are trying to pervert the gospel of Christ." In other words, he heard that Galatians were deceived by 'a different gospel' and presented his experience of revelation in the process of testifying that only the gospel he preached was true.

Gal 1:11-17: "11 I want you to know, brothers and sisters that the gospel I preached is not according to men. $12 \mathrm{I}$ did not receive it from any man, nor was I taught it; rather, I received it by revelation from Jesus Christ. 13 For you have heard of my previous way of life in Judaism, how intensely I persecuted the church of God and tried to destroy it. 14 I was advancing in Judaism beyond many of my own age among my people and was extremely zealous for the traditions of my fathers. 15 But when God, who set me apart from my mother's womb and called me by his grace, was pleased 16 to reveal his Son in me so that I might preach him among the Gentiles, my immediate response was not to consult any human being. $17 \mathrm{I}$ did not go up to Jerusalem to see those who were apostles before I was, but I went into Arabia. Later I returned to Damascus."

In verses 11-12, Paul says that the gospel he preached is

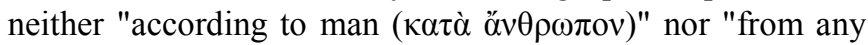

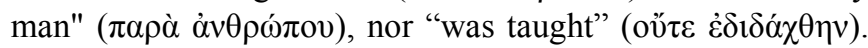
"According to man" means not according to an artificial way, and verse 12 shows that he did not receive the gospel as a tradition passed down to the church. That is, the reinterpretation of the artificial method ('according to man') in verse 11 is contained in verse 12 [4]. Paul makes it clear that the gospel he preached is not connected with man in any way. How then did Paul learn of the gospel? It is through

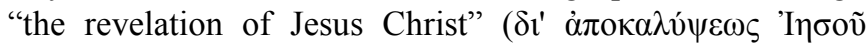

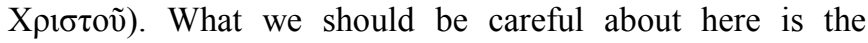

relation of the possessive "Jesus Christ" and the noun "revelation" ( $\dot{\alpha}$ ок $\alpha \lambda v ́ \psi 1 \varsigma$ ), which can be interpreted as an object possessive (Gen. obj.). In other words, the content of the revelation itself is Jesus Christ, an interpretation that can be inferred through verse 16 . "God was pleased to reveal his Son God in me." What Paul is saying is clear. The revelation that he received has led him to the recognition and truth of the gospel. That is why he could confidently say, not through man, but only "through the revelation of Jesus Christ."

In verses 13-14 Paul emphasizes the fact that he was a Jewish believer who once worked diligently. Emphasizing that he tried to take the roots at the same time, saying that he went one step further and persecuted Christians (1Cor 15:9; Phil 3:6). It is evident that Paul's character was enthusiastic when persecuting or preaching the gospel. He said that he kept the "the traditions of my fathers" ( $\pi \alpha \tau \rho \iota \kappa \tilde{\omega} \nu \mu o v$ $\pi \alpha \rho \alpha \delta$ ó $\sigma \varepsilon \omega v)$ harder than anyone else, but it was a required course of the Jewish law of education, the interpretation of the Rabbi who had been orally proclaimed the in tradition of the ancestors. In this expression, it is possible to speculate that Paul was educated in the formal course to become a Rabbi [5].

Paul then summarizes the contents of his revelation in one sentence in verses 15-16. In short, the resurrected Jesus

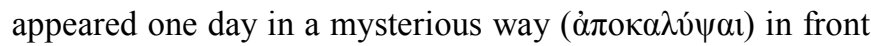
of Paul, giving the mission "to preach Jesus among the Gentiles." It is a simple sentence, but it actually has a complex structure (infinitive, conjunction sentence) that contains various ideas. Paul emphasized in verses 11-12 that his mission of preaching the gospel was never done in a human way. So how did he get his mission? Paul used a circumstantial phrase, "But when God, who set me apart from my mother's womb and called me by his grace (ö $\tau \varepsilon \delta \dot{\varepsilon}$

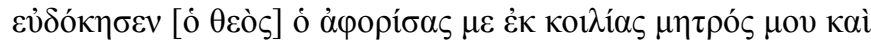

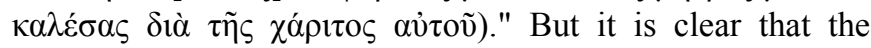
initiative of revelation was in God. "By his grace" is equivalent to "by the grace of Christ" of verse 6 . Therefore, it is not necessary to consider that God takes the initiative of grace and Jesus is in a passive position relative to God [6].

God "was pleased to reveal his Son in me [Paul]." The tricky part of this passage is the expression 'in me'. In this case, the preposition ' $\dot{\varepsilon} v$ ' used here is the primary meaning of 'in' (Gal 2:20, 2 Cor 13:3, Rom 8:23) it can also mean 'to' (Gal 1:24, 1 Cor 9:15) [7]. In other words, the revelation may have come from within me or from outside. If the revelation came from outside, it would fit well in the conversion case of Acts 9 [8]. If it came from inside, "God, who said, 'let light shine out of darkness' made his light shine in ( $\dot{\varepsilon} v)$ our hearts to give us the light of the knowledge of God's glory displayed in the face of Christ." (1 Cor 4:6) [9] It is not known exactly through the context of verse 16 .

To correctly understand this passage, we need to check that two facts become clear when Jesus is revealed 'in me'. One is the mission to preach Jesus to the Gentiles, and the other is that this has already been decided on the mother's side. To preach Jesus to a Gentile is future-oriented action from the point of view of Paul's revelation, but already been decided 
from the mother's womb is past-oriented. It means, God has decided to make Paul an apostle of the Gentiles since Paul's life began.

\section{The Mystic Experience of Dasuk}

Youngmo Ryu (柳永模) Dasuk [10] (March 13, 1890 February 3, 1981) was a Korean thinker, educator, philosopher, and religious figure. He lived in hard times such as the colonial period, the liberation from Japan, and the Korean War - really times of upheaval. He wrote the articles of Faith in Bible Joseon (聖書朝鮮. 1927-1942), a magazine that gave courage to the Koreans who were thirsty for free faith and free thought at the time of Japanese occupation. He was one of the outstanding writers of the Bible Understanding. Although Dasuk was a pioneer who accepted Christianity, he was accustomed to the learning of the time. He was also proficient in traditional Korean religions such as Confucianism, Buddhism, and Taoism. In other words, it is clear that he was a Christian pioneer but did not abandon Korean tradition [11]. He is a unique person in the era of turmoil when Western theology took control the Korean Christianity.

Dasuk reached a great enlightenment at the age of 52 years. It is the day of January 4, 1941. After getting great enlightenment, Dasuk called the day of enlightenment 'Rebirth Day', and published the joy of that day in Bible Joseon (March 1942), 'Song of the One who entered into the faith'.

Verse 1: I have no sorrow

No sorrow from now.

You occupied me,

You took care of me.

You, I belong to.

Verse 2: I throw away my body and face.

I left all my stuff.

"What should I do before I die?"

"What other people say?"

It is all gone.

As a new body of life

Take that Word ( $\lambda$ ó $\gamma$ o $\varsigma$ ).

Verse 3: As a new face of life

This universe appears

I took all the action lines.

All things (萬有物質) lined up.

Look around the world, not on the outside.

Leaning on nothing, away from personal

Verse 4: Sparkle! Light! (John 1:1-4)

The face [of Dasuk] is facing you

The Light acquired Word.

Verse 5: The face is to see you.

The body is to read Word.

The face is to love.

The body is to hold the Meaning, Amen

The original vocabulary of this poem has been changed into modern grammar to make it easy to understand as long as it does not damage the contents. Dasuk wrote in free-form style, but the inner structure is noticeable. The first verse describes the relationship between God and Dasuk, in verse 2 he explains how he is changed as a result of God's undertaking, verse 3 presents the prospects in his changed life, and verse 5 organizes himself once again. It is the development of the familiar idea based on introduction, development, turn, and conclusion, four steps in composition. Particularly noticeable is the verse 4 , so called exclamation (추임새).

Verse 4 is the realistic expression of the moment when he experienced God. Dasuk saw the twinkling light and saw himself completely exposed in front of the light. It was in his

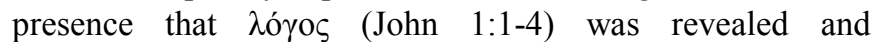
experienced the $\lambda$ ó $\gamma$ os. In the Damascus experience of Acts 9, Paul says that his eyes are temporarily blinded because of the strong light [12], which is reminiscent of the Dasuk's experience. If we can bring back the experience of Damascus to Paul himself, Paul can also be seen as experiencing Jesus who came as light. The next noteworthy section is verse 3 .

As Dasuk enjoys his new life, an important change comes to him. In the body, the Word (Jesus) is fully brought up, and in the face, "This universe appears/I took all the action lines/All things lined up" What is this universe? What does all action mean? What does it mean all things lined up? Perhaps the most difficult part of this poem, I have been searching through the books about Dasuk, but I have not yet found an interpretation that fits my eye. Here is one possible guess.

In my opinion, this verse is a description of the changes that have been made to Dasuk by the experience of God. After the change, Dasuk sees all the actions he has ever done as a line, and all the things (萬有物質) [13] have settled on the line. In other words, it means that Dasuk's past and present can be seen at a glance, and the context can be read, so that he can lay down all of his life. And if the past and the present were put in this way, it could have been regarded as the event in which 'this universe' appeared. What kind of experience is it that the past and the present of the past can be revealed clearly and reach the universe? It is possible to get a clue to this question if we follow the development of Dasuk's thought for decades after the experience of God.

"In this way, living should be called 'here now'. It is a very good discovery that 'I am here' than any other. This is true. So even the widest world is 'here' and the longest world is 'now'. It is Gaonggigi (가온찍기) [14]. From this point I am reaching out to the world. So Gaonggigi is the origin of the world and origin of 'I' too." [15]

The first question given to Dasuk by this poem is 'Who am I?' I live in a corner of this universe! What is it worth to me? The answer to that question is found in the Gaonggigi, and Dasuk is now expanding its scope to God, the source of all life and the source of all. It is so-called 報本追遠, to celebrate the grace of the ancestor.

"If our lives are ever blooming, we will reach 空 (the Emptiness, Absoluteness). It is eternal life. 空 is the first source of life and the source of all. It is God. I also think of a personal God. God is personality, but not like ours. Personality means transcending the existence and the absence. 
You should not be satisfied with the material when you are looking for God. I am not satisfied with what I am looking for. So God is be without being."[16]

For Dasuk, 'Universe' is another name of God. After Dasuk's lifetime study, he expressed God in terms of 'Emptiness'(空, 빔), 'Be without being'(없이 계신 이), 'True One'(참하나) and so on [17], but when he first experienced God, through this revelation the universe poured into Dasuk's life. As a result, he was perceived by God (You occupied me/You took care of me/You, I belonged to), so realized the change of existence. Therefore, from now on, there is no self in the past, and remains only "the face to see you and the body to read the Word." God's intervention has brought about a change of being.

This is the result that the change of being brought up on a practical level. As mentioned in verse 2, he no longer has the question of "what should I do before I die?" or "what other people say?" All other world affairs, except for the experience of the pure God, have lost meaning. Now we return to the experience of Paul.

\section{From Mother's Womb}

Paul confidently states that his mission was determined from his mother's womb. The general view of scholars is that the expression 'chosen from the womb' is derived from the Old Testament (LXX). For example, Isa 49:1, "Listen to me, you islands; hear this, you distant nations: Before I was born the Lord called me; from my mother's womb he has spoken my name. [18]" and in Jer 1:5, "Before I formed you in the womb I knew you [19], before you were born I set you apart; I appointed you as a prophet to the nations." So Paul, who was accustomed to the Old Testament, could say that he had put the story of prophet's call to his experience.

The reason why Paul borrowed the Old Testament expressions is that his revelation is an extension of Isaiah and Jeremiah. And this may also include the intention to be recognized by those who know the prophetic experience of the prophets. The scholar standing at the front of this view is O. Betz. He said that Paul borrowed the expression "from the womb" used in Isaiah specifically to claim the legitimacy of the Damascus case, which is the basis of his apostolate in the apostolic debate in the first century church [20]. But if Paul tried to convince the other apostles of his legitimacy of the apostolate, verse 17 "I did not immediately go to Jerusalem to meet anyone who had not discussed with anyone and was an apostle before me" would not have been necessary.

As we have seen, it contains implications in Paul's expression that he knew the Septuagint. However, the question that still remains unresolved is whether the intentions of such expressions end up being rhetorical expressions [21]. There is a fundamental agreement on the experience of revelation between the basis of the Old Testament prophets and extensions of Paul. Therefore, the question why Isaiah, Jeremiah, and Paul mother's womb mentioned still remains.

When Dasuk experienced God, he confessed that he took all the action lines and all things lined up. When Paul met with God, he would have a marvelous experience unfolding all his life before God. So he became aware that his destiny was determined through his mother. In other words, "set me apart from my mother's womb" is not a simple rhetorical expression. Although we do not know exactly what Paul saw, but God appeared in a flash of light and showed Paul's life in full before him. And the same experience would be shared by Isaiah and Jeremiah.

In fact, this is a logically reasonable guess. For God will not have a passing past, the visible present, and the future that will come. Even though the life experience of Paul and Dasuk are past events, it is a meaningless time-lapse for the eternal present God (Ewige Gegenwart) [22]. Therefore, in Paul's view, God's plan, which had begun from the womb in the past, would be made in the future by the proclamation of the gospel, but to God it would have seemed as if they were in one line.

Paul did not doubt the fact that his apostolate call was directly received by God. So, even though no one asked whether he ever visited Jerusalem, he added it in verse 17. This would certainly mean that he didn't feel the necessity of confirming his apostolate before the leaders of the Jerusalem Church, the disciples of Jesus. Instead, Paul immediately went to Arabia and returned to Damascus.

Between Paul and Dasuk, there is a time interval of 2,000 years and a space distance between the Mediterranean Sea and Far East Asia. It seems to be a difference that can't be narrowed in any way. However, we can find some commonalities in the experience of the two. Let me list them one by one.

First, Paul and Dasuk experienced a strong light while experiencing God, and at the same time they could look at their lives as if they were putting things on a line. Dasuk says, "as a new face of life/this universe appears/I took all the action lines/all things (萬有物質) lined up" And Paul says, "when God, who set me apart from my mother's womb and called me by his grace, was pleased to reveal his Son in me so that I might preach him among the Gentiles," In front of eternal present God, Paul and Dasuk both have been exposed to his life in the manner of God.

Next, meeting with God is a pure experience that can't be replaced at all. Also, this was not done in an artificial way (Gal 1:12). Therefore, Paul did not feel the need to go to the Jerusalem Church to explain his experience. The Jerusalem Church was the first church established in Christian history and was a community led by the disciples of Jesus. Paul also acknowledged the authority of the Jerusalem Church [23], but his experience of God was of a nature in which the Jerusalem Church could not intervene.

After the experience of God, it was the same with Dasuk who was no longer conscious of others. So he sings, "I left all my stuff/what should I do before I die?/what other people say?/It is all gone." This kind of revelation can be a very dangerous idea for the institutional church in which the experience of God in any form must be brought into the system. This is because there is a possibility of 
misinterpretation as a Private Revelation without legitimacy.

The greatest commonality in the experience of the two is 'change of being'. Dasuk says that he himself has been occupied, possessed and belongs to God entirely by body and mind. Paul looked back at his life after a moment of experience and knew that God had decided to use himself from his mother's womb to be an apostle of the Gentiles. It was a remarkable confession, because he was once a persecutor of Christianity. It was a Copernician transition to the concept of identity when compared with the teaching of Judaism, which cried out that Jew's identity must be established as the people of God when strictly obeying the law. The ultimate question of Paul and Dasuk is changed from "What am I doing?" to "Who am I?"

\section{Conclusion}

One day Paul and Dasuk experienced God. After the experience, Paul was transformed into an apostle for the Gentiles, and Dasuk was born again ('Rebirth Day'). When we compare the experience between the two people, as we have seen before, common things that can't be ignored are found. They stood before the eternal present God, untouched by time, through which they experienced the dramatic change.

The content of the question has changed from the ethical level to the existential level [24]. The experience of God is the enlightenment that brings about a Change of Being. Therefore, in life after enlightenment, revelation and calling would never be divided into two [25]. It is an excellent example of Paul, who had spent his entire life as a gospel preacher, and Dasuk, who lived a lifetime as an educator devoted to explaining the words of God. He was the head teacher of Osan School after 1921 and taught the YMCA 'Seminar Lecture of Bible' (呼經班講義), which lasted for 35 years from 1928 to 1963 , It is a way to discover the true value of Dasuk as a Bible teacher and as an educator.

Paul cherished his religious experience of meeting Christ, and devoted his life to the path of his life. In Buddhist terms, he entered the status of 'Sudden Enlightenment, Lifelong Discipline’ (頓悟漸修) [26] The path of Paul is very similar to Dasuk's life. Paul says of his change in Gal 2:19-20, "For through the law I died to the law so that I might live for God. I have been crucified with Christ and I no longer live, but Christ lives in me. The life I now live in the body, I live by faith in the Son of God, who loved me and gave himself for me."

Dasuk also shows the same status, and when he sees another poem in which he sings the experience of God,

Lord, take this off.

Take this offense

I miss my life.

Let's forget the body!

Let's take face off!

Let's empty heart!

Take the meaning of the sender!

Along the note,

Let's fulfill the word of the Father.
With the Word

Let's live! Amen.

- Bible Joseon -

\section{References}

[1] The year of Paul's alteration is unknown. It is even harder to know what process he met and made up with Jesus. However, the fact that Paul had never seen Jesus alive, and based on the report that Paul was in a place where Stephen was dying (Acts 7: 58) it can be roughly assumed to be around 33-35 AD.

[2] "Paul and other Jewish believers in Christ did not think of themselves as moving from one religion to another. Moreover, here Paul's language clearly refers to the prophetic call of Servant in Is 49 and the prophet Jeremiah. Consequently, Stendahl and those following him insist upon the term 'call' rather than 'conversion.'” (F. J. Matera, Galatians, Sacra Pagina 9, Minnesota: The liturgical Press, 1992, p. 62).

[3] "And that he appeared to Cephas, and then to the Twelve. After that, he appeared to more than five hundred of the brothers and sisters at the same time, most of whom are still living, though some have fallen asleep. Then he appeared to James, then to all the apostles, 8 and last of all he appeared to me also, as to one abnormally born."

[4] Mussner translates verse 12a, "Because I did not receive it from any man, nor was I taught it;" He regards conjunction $\gamma \grave{\alpha} \rho$ in verse 12 as the conjunction which receives the entire sentence. (F. Mussner, Der Galaterbrief, HThK 9, Freiburg: Herder, 1981, p. 65).

[5] When a young Jewish man decides to become Rabbi, he visits a Rabbi who he liked and is educated. There were usually three subjects in the curriculum: (1) memorization of the Bible (law and prophecy), (2) interpretation of the law (Midrash), and (3) rhetoric. Paul's letter shows that although he did not reveal himself, he studied professionally. As well as his confession that he kept the ancestral tradition 'the traditions of fathers' (2), his skill to quote the law and the prophetic verse from time to time is sufficient to view the systematic training of the law (1). Also, various rhetoric as well as poetry talents (1 Corinthians 13) were also outstanding (3). It is a passage that makes it possible to speculate that Paul was systematically educated. In fact, none of the wandering preachers (Wandercharismatiker) at that time had the ability to logically criticize the law like Paul. It is also a key to support the possibility of studying Paul. In the book of Acts, Paul tells us that he studied in Jerusalem and studied under Gamaliel, a distinguished scholar of the day (Acts 22: 3).

[6] "The Interchange of God and Christ in the phraseology highlights the fact that Paul thought of God and Christ as completely at one in mankind's salvation.'(R. N. Longenecker, Galatians, WBC 41, Dallas: World Book Publisher, 1990, p. 30).

[7] The usages of the preposition ' $\varepsilon v^{\prime}$ are space, time, qualifications, tools, causes, etc.

[8] F. Mussner, Der Galaterbrief, 84-85; H. Lietzmann, An die Galater, HNT 10 (Tuebingen: J. C. B. Mohr 1923), p. 8.

[9] O. Betz, "Die Vision des Paulus im Tempel von Jerusalem. Apg 22, 17-22 als Beitrag zur Deutung des Damaskuserlebnis", in: Verbum Veritas. Festschr. f. G. Staehlin (Wuppertal 1970), p. 82. 
[10] Dasuk (多夕), the pen name of Youngmo Ryu, means to eat only one meal in the evening without instead of eating all three meals.

[11] "Dasuk was an Oriental person who was deeply touched by Confucian, Buddhist, Taoism, and after reading the Bible, he established his own theology, Christology, and life view. Dasuk wanted God's sight, and it is the belief that everything originates from Father God, the Emptiness (空), and returns to Him (歸一神觀), theos-central religious pluralism." (Yangmo Chung, I see Dauk like This, Seoul: Durea Publisher, 2009, p. 59).

[12] A light that is strong enough to eliminate a person's vision is said to be when the temperature exceeds 2,000 degrees. In the Gospels, when Jesus went up to the mountains with his disciples, his clothes were shining white so that no launderer could imitate them (Mark 9: 2-8), and the glory of God was like a fire burning a mountain peak (Exod 24: 17). A strong, bright light is a phenomenon that appears when God exposes himself, and can't withstand the power of the human eye.

[13] 萬有物質 can be translated carefully into 'reason' or 'logic'.

[14] Gaongiggi (가온찍기) is a way of expressing the coming and going of eternity with the unique ideas of Dasuk. It is pointing in the middle of coming and going forever. If it is expressed in Korean, it becomes " $\lceil\cdot\rfloor$ ". Gaonggigi is the moment when we realize the truth and the moment we meet eternity. Thinking, thinking, missing, missing the sky, it is the key to life.

[15] Dasuk Accademy, Dasuk's Lecture (Seoul: Hyunam Publisher, 2006) p. 42.

[16] Dasuk Accademy, Dasuk's Lecture (Seoul: Hyunam Publisher, 2006). p. 285.

[17] "What is essential for Dasuk is the East Asian ethos that 'the one who is without being', whom also 'Bintang'(빈탕. Emptiness), is within oneself, because God is the true 'I'."'(Lee Jung-Bae, "Finding a way to the Indigenition and Globalization of Christianity" in: God who is without Being, Men who is less without Being, Seoul: Mosinunsaramdeol Publisher, 2009, p. 347).

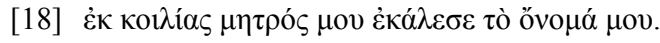

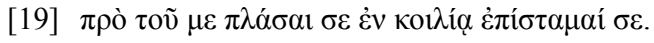

[20] O. Betz, "Die Vision des Paulus ...." p. 117-118.

[21] "It is probably best, however, as with any idiomatic expression, to allow a measure of ambiguity and to translate it here simply 'from birth"'(R. N. Longenecker, Galatians, p. 30).

[22] The expression "Ewige Gegenwart" is derived from the New Testament scholar R. Schnackenburg (Das Johannesevangelium, HThK IV-2, Freiburg: Herder, 1985, p. 243) As scholars argue that God's time is different from human physical time and qualities, PM-J. Lagrange says that God exists from the very beginning without time coordination (Evangile selon Saint Jean, Paris: Liberarie Lecoffre, 1936, p. 256), R. E. Brown has stated that there is no scientific basis for the way God exists (According to Gospel According to John, AncB 29, New York: Doubleday, 1983, p. 366), and U. Schnelle says, the fact that there is no boundary in the time of God means that God is the master of time (Herr der Zeit) (Das Evangelium nach Johannes, ThHK 4, Leipzig: Evangelische Verlaganstalt, 1998. p. 163).

[23] Rom 15: 23-27: "Now, however, I am on my way to Jerusalem in the service of the Lord's people there. 26 For Macedonia and Achaia were pleased to make a contribution for the poor among the Lord's people in Jerusalem. 27 They were pleased to do it, and indeed they owe it to them. For if the Gentiles have shared in the Jews' spiritual blessings, they owe it to the Jews to share with them their material blessings."

[24] It is Paul's thinking that consistently reflects human existence deeply in his relatively early ideas, 'in Christ', 'regeneration', 'new creation' or 'justification', also known as the complements of Pauline theology.

[25] S. Lēgasse, L'épittre de Paul aux Galates (Paris: Le Edition du Cerf, 2000) p. 94. Especially G. Strecker saw the calling of God and the repentance of Paul as a unit, and this was linked to Paul's concept of "love" in the future (G. Strecker, "Befreiung und Rechtfertigung", in: Eschaton und Historie, Goettingen: Vandenhoeck \& Ruprecht, 1979, pp. 235-36).

[26] “The East Asian Zen (禪) tradition has long understood enlightenment to be a sudden flash of insight rather than a gradual revelation."(https://tricycle.org/trikedaily/slowmotion-satori/). 